\title{
ANNOTATED LIST OF THE MAMMALS OF NOVA SCOTIA
}

\author{
FRED W. SCOTT ${ }^{*}$ and ANDREW J. HEBDA ${ }^{2}$ \\ ${ }^{1}$ Research Associate, Nova Scotia Museum of Natural History, \\ and Curator, Wildlife Museum, Biology Department, \\ Acadia University, Wolfville NS BOP 1 XO \\ ${ }^{2}$ Curator of Zoology, Nova Scotia Museum of Natural History, \\ 1747 Summer Street, Halifax, NS B3H 3 A6
}

The latest taxonomic, distributional, habitat and conservation status information is presented for a total of 91 species of marine and terrestrial mammals presently or historically known from Nova Scotia. Four of them are extirpated and one is extinct. Of the 86 remaining species 51 are terrestrial (46 native, 5 introduced). The terrestrial mammals include 9 species of Insectivora, 6 (+ one tentative) of Chiroptera, one Primate, 12 Carnivora, 1 Perrissodactyla, 3 Artiodactyla, 19 Rodentia and 1 Lagomorpha. Native species include Boreal, Transition Zone and Austral elements, the result of Nova Scotia's mid-latitude position on the continental coast.

The 32 recorded marine species include 6 Carnivora ( 5 seals, walrus) and 26 Cetacea: Delphinidae (10 species), Phocoenidae (1), Monodontidae (1), Kogiidae (2), Physeteridae (1), Ziphiidae (4), Eschrichtiidae (1, extirpated), Balaenopteridae (5) and Balaenidae (1).

Since 1971 four small mammal species (Sorex gaspensis, S. dispar, Glaucomys volans and Microtus chrotorrhinus) have been added to the provincial fauna, as a result of the first systematic and intensive sampling ever done in Nova Scotia. All are disjunct and three of them are restricted to forested talus habitats in the Cobequid Mts. or the Cape Breton Highlands. With the two disjunct species already known (Sorex arcticus maritimensis and Peromyscus leucopus caudatus), there are 6 disjunct mammals in the province, comprising $14.3 \%$ of native non-volant terrestrial mammals, $33 \%$ of insectivores and $18.8 \%$ of native rodents. Two of them (Sorex gaspensis and Microtus chrotorrhinus) occur only on Cape Breton Island. No other area of similar size north of Mexico has a comparable proportion of disjunct mammals.

Cape Breton Island historically has had a depauperate mammal fauna, lacking 8 species that were present on the adjacent mainland. The building of the connecting Canso Causeway in 1953-55 had a major zoogeographic impact, as it caused the western third of the strait to freeze over in winter and allowed the invasion and establishment of four large mammal species (Canis latrans, Procyon lotor, Mephitis mephitis and Lynx rufus).

Le document présente l'information la plus récente sur la taxonomie, la répartition, l'habitat et la situation de 91 espèces de mammifères marins et terrestres qui vivent actuellement ou ont déjà vécu en Nouvelle-Écosse. Quatre d'entre elles ont disparu et une est éteinte. Sur les 86 autres espèces, 51 sont terrestres (46 espèces indigènes et 5 espèces introduites). Les mammifères terrestres comprennent 9 Insectivora, 6 (+ une espèce provisoire) Chiroptera, un Primate, 12 Carnivora, un Perrissodactyla, 3 Artiodactyla, 19 Rodentia et un Lagomorpha. La Nouvelle-Écosse étant située à une latitude moyenne sur la côte continentale, les espèces indigènes qui y vivent sont des éléments de la zone boréale, de la zone de transition et de la zone australe.

Parmi les 32 espèces marines signalées, on compte 6 Carnivora important a ( 5 phoques et le morse) et 26 Cetacea: Delphinidae (10 espèces), Phocoenidae(1), Monodontidae(1), Kogiidae(2), Physeteridae (1), Ziphiidae (4), Eschrichtiidae (1, disparue), Balaenopteridae (5) et Balaenidae (1).

Depuis 1971, à la suite du premier échantillonnage systématique et intensif mené en NouvelleÉcosse, quatre espèces de petits mammifères (Sorex gaspensis, S. dispar, Glaucomys volans et Microtus chrotorrhinus) se sont ajoutées aux espèces fauniques de la province. Ce sont toutes des espèces disjointes, et trois d'entre elles sont confinées aux talus d'éboulis boisés des monts Cobequid ou des hautesterres du Cap-Breton. Si on inclut les deux espèces disjointes déjà connues (Sorex arcticus maritimensis et Peromyscus leucopus caudatus), il existe 6 espèces disjointes de mammifères dans la province, qui représentent 14,3 \% des mammifères terrestres indigènes qui ne volent pas, 33 \% des Insectivores et 18,8 \% des Rongeurs indigènes. Deux d'entre elles (Sorex gaspensis et Microtus chrotorrhinus) ne sont présentes que dans l'île du Cap-Breton. Au nord du Mexique, aucune autre région de taille semblable n'a une telle proportion d'espèces disjointes de mammifères.

Dans le passé, l'île du Cap-Breton renfermait relativement peu de mammifères : on y trouvait 8 espèces de moins que dans la partie continentale de la Nouvelle-Écosse. La construction de la levée de Canso en 1953-1955 a eu un impact important zoogéographique du fait que, depuis, le tiers ouest du détroit gèle durant I'hiver, ce qui a permis à quatre espèces de gros mammifères (Canis latrans, Procyon lotor, Mephitis mephitis et Lynx rufus) de gagner l'île et de s'y établir.

* Author to whom correspondence should be addressed. 


\section{Introduction}

A first step in any conservation effort is an assessment of what is already known, particularly on the fundamental questions of what species live in an area, where and when they occur, and how abundant they are. Comprehensive and current annotated taxonomic checklists provide a temporal and spatial overview of the biodiversity of a group in a region or jurisdiction, and an entry point to the important literature.

This list was first compiled by FWS in 1993 while Assistant Curator of Zoology at the Nova Scotia Museum of Natural History, and revised as necessary. Since moving to Acadia University in 1995, he and AJH have jointly continued to update the list and make it available to all interested parties. The decision to publish it was prompted largely by the fact that it has been 62 years since the appearance of the last provincial list (Smith 1940), which was limited to land mammals. The taxonomy used by Smith is seriously out of date and there have been major additions of species, range extensions and changes in status since then.

Future revisions and updates of this list will be posted on the Nova Scotia Museum of Natural History website at http://museum.gov.ns.ca/mnh/index.htm.

\section{Taxonomy}

The higher taxonomy adopted is that of Wilson \& Reeder (1993), with the exception of the placement of the cougar in the subfamily Acinonychinae, in accordance with molecular genetic work by Janczewski et al. (1995). Wilson and Reeder also list taxa from family level down in strictly alphabetical order and this conveys nothing about supposed relatedness, so at those levels we have retained the traditional sequences of families, genera and species. Wilson and Reeder's species definitions have also been adopted, except for our retention of Myotis septentrionalis as separate from M. keeni (van Zyll de Jong 1985). Subspecies are not explicitly considered in this list unless they constitute disjunct Nova Scotian populations. Common names are generally those used in Banfield (1974), with modifications based on more recent usage, and alternate or formerly accepted names in parentheses. Colloquial names widely used in Nova Scotia are in quotation marks.

\section{Information sources}

The standard references for distribution and biology are Peterson (1966) and Banfield (1974); only overlooked old information, corrections to published literature, significant new information, or occurrences of rare or new taxa, are separately referenced in this list.

For most mammals, especially the small non-marine species, the status, distribution and habitat preferences are based on the largely unpublished collection records of the Nova Scotia Museum of Natural History and the Wild life Museum at Acadia University, mostly from 1971 onwards. Also included are all records from the Canadian Wildlife Service surveys of the mammals of Kejimkujik and Cape Breton Highlands National Parks in 1971 and 1974, as well as about 1500 records of small mammals from Nova Scotia in collections of other North American museums. All of these records are attributed here as the Nova Scotia Mammal Collection Record Database (NS MCRD). Most of them (5278 of approximately 7081) are accessible online at the Nova Scotia Museum of Natural History; all are accessible through FWS at the Wildlife Museum, Acadia University. Specimens in the collection of the Nova Scotia Museum of Natural History are referenced as (NS MNHC); non-collection information in that museum's files is referenced as (NS MNH). 
For managed terrestrial game and furbearing species, and for some others, the latest status information is from the Nova Scotia Department of Natural Resources Wildlife Division, Kentville NS, and referenced as (NS DNR).

Until recently the great majority of precisely located cetacean records were strandings of dead animals, which do not necessarily reflect living distribution or abundance. We chose to cite significant stranding occurrences because they are often historically important and because many of those animals also ended up in permanent museum collections and in the published literature. Strandings are listed first in the species accounts. Nova Scotia stranding records from 1949 to 1970 are summarized in Sergeant et al. (1970); the most recent summary of strandings for Sable Island covers the period from 1970 to 1998 (Lucas \& Hooker 2000). Stranding records not cited from these or other publications are from the Nova Scotia Marine Animal Stranding Report Database (MASRD), now held at the Nova Scotia Museum of Natural History, Halifax. In addition to summarizing the current knowledge of the status of wild populations, we have also made a point of citing all notable reliably identified published or unpublished sight records of live animals, since they more accurately represent the distribution and habitat preferences of wild populations.

\section{Conservation status}

Formal conservation status is indicated when it has been assigned. On the national level status is assigned by COSEWIC (Committee on the Status of Endangered Wildlife in Canada). In Nova Scotia, an ad hoc Species at Risk Working Group was established in late 1996 by the Wildlife Division of the Nova Scotia Department of Natural Resources to provisionally evaluate and rank Nova Scotian biota, pending the enactment of formal legislation. FWS was a member of that ad hoc committee's Mammal Working Group. Rankings were based on the then-current IUCN criteria and were summarized by colour code: RED (known or believed to be at risk of extinction or extirpation); YeLLOW (known or believed to be particularly sensitive to human activities or natural events); GreEN (known or believed to be not at risk from human activities or natural events). All native non-marine mammals have been provisionally ranked.

With the passage of the Nova Scotia Endangered Species Act (1998) (NSESA) a formal Species At Risk Working Group (SARWG) was established which is evaluating and ranking all species, with the priority on those with existing COSEWIC status, and those provisionally ranked Red by the ad hoc Working Group. FWS is also a member of SARWG.

\section{Annotated list}

\section{ORDER INSECTIVORA (SHREWS, MOLES, TENRECS, HEDGEHOGS)}

Family Soricidae (Shrews)

1. Sorex arcticus Kerr 1792, subspecies maritimensis Smith 1939. Arctic Shrew (Saddle-backed Shrew, Black-backed Shrew). Green (NS). Disjunct. Population in NS/southeast New Brunswick (ssp. maritimensis) is widely separated from main population north of the St. Lawrence River and van Zyll de Jong (1983) suggested it was a good species; chromosomal (Volobouev \& van Zyll de Jong 1988) and new DNA analysis (Fumagalli et al. 1999, Stewart et al. 2002) support recognizing this population as specifically distinct (Sorex maritimensis Smith). Mainland only. Locally common in floodplain wet meadows and marsh margins, especially dyked coastal marshland in Kings and Cumberland Counties (NS MCRD). Its 
apparent inability to colonize adjacent habitats makes it especially vulnerable to increased winter/spring flooding caused by climate warming (Herman \& Scott 1992).

2. Sorex cinereus Kerr 1792. Common Shrew (Masked Shrew, Cinerous Shrew). GREEN (NS). Common throughout, including many coastal islands, and found in all but permanent wetlands and urban habitats. Probably the most abundant of all NS mammals; populations fluctuate irregularly (NS MCRD). The only native small mammal on Seal Island, $24 \mathrm{~km}$ from the mainland. Populations on Seal and Bon Portage Islands show some genetic differences from mainland populations (Stewart \& Baker 1992).

3. Sorex fumeus Miller 1895. Smoky Shrew. GreEn (NS). Mainland only; Cameron's (1958) single Cape Breton Island record was a misidentified old S. cinereus (NS MCRD). Common in deciduous and mixed forests, especially along streams; uncommon to occasional in other forest or tall shrub habitats (NS MCRD).

4. Sorex gaspensis Anthony \& Goodwin 1924. Gaspé Shrew. SpeCial Concern (COSEWIC 1988). Yellow (NS) Disjunct. First collected in 1971 on Kellys Mtn, but initially misidentified (Scott \& van Zyll de Jong 1989); discovered in 1974 in Cape Breton Highlands National Park (Roscoe \& Majka 1976). Rare and very local on forested talus around periphery of Cape Breton Highlands (Scott 1988). Differs morphometrically from $S$. dispar only in size, not in shape, and the two may be conspecific (Scott \& van Zyll de Jong 1989). DNA comparison of the two is under way by FWS and Don Stewart of Acadia University.

5. Sorex dispar Batchelder 1911. Long-tailed Shrew (Rock Shrew). Yellow (NS). Disjunct. Discovered in 1984 (Scott 1987). Rare and very local on forested talus in the Wentworth Valley (Scott \& van Zyll de Jong 1989) and Portapique River Valley (Woolaver et al. 1999) of the Cobequid Mountains.

6. Sorex palustris Richardson 1828. Water Shrew. GreEN (NS). Uncommon and local throughout along streams, lake shores and sometimes rocky coasts (NS MCRD).

7. Sorex hoyi Baird 1857. Pygmy Shrew. Green (NS). Uncommon and very local throughout, in floodplain marsh margins, oldfields, regenerating clearcuts and mature forests, including those on talus slopes (NS MCRD).

8. Blarina brevicauda (Say 1823). Short-tailed Shrew ("mole"). Green (NS). Common throughout in all but permanent wetlands and urban habitats; populations fluctuate irregularly (NS MCRD).

Family Talpidae (Moles)

9. Condylura cristata (Linnaeus 1758). Star-nosed Mole. Green (NS). Locally common throughout where soils are suitable, especially near permanent water (NS MCRD).

\section{ORDER CHIROPTERA (BATS)}

Family Vespertilionidae (Plain-nosed Bats)

10. Myotis lucifugus (Le Conte 1831). Little Brown Bat. Yeltow (NS). Occurs throughout; most abundant and widespread of our bats. Forms maternity colonies in buildings, sometimes with thousands of bats. Hibernates in caves and mines. Only one large hibernaculum known, at Hayes Cave, Hants Co. (6000-9000 bats) (Scott 1985). Second largest known is in an abandoned mine at Lake Charlotte ( 3000 bats; NS DNR). About 11 smaller hibernacula (25-1000 bats) known, in caves or abandoned mines (Taylor 1997). Total known wintering population is about 15,000, out of an estimated Nova Scotia population of 300,000 (Scott 1995). 
11. Myotis septentrionalis (Trouessart 1897). Northern Long-eared Bat. YelLow (NS). Uncommon throughout, apparently seldom in buildings. Hibernates in small numbers in caves and mines, at most if not all of the sites used by lucifugus, and possibly some by itself (NS MCRD).

12. Pipistrellus subflavus (F. Cuvier 1832). Eastern Pipistrelle. Yellow (NS). Rare, western and central mainland only; apparently never in buildings here. Hibernates in caves and mines. Only 2 non hibernating records (NS MCRD); present in small numbers in Hayes Cave from late 1950s to 1963 but not seen there since (Scott 1985).

13. Lasionycteris noctivagans (Le Conte 1831). Silver-haired Bat. Yellow (NS). One summer record, Kejimkujik National Park (NS MCRD). Probably migratory.

14. Lasiurus borealis (Müller 1776). Red Bat. YelLow (NS). Rare, probably widespread. Migrates. 3 specimen records (NS MCRD). The first confimation of breeding came in August 2001 when a female and four young were discovered by Bob and Tracy LeBlanc in a horse-chestnut tree at Sand Beach near Yarmouth and observed/photographed over several days before they left (Lavers 2002); copies of the photos are on file at NS MNH and DNR.

15. Lasiurus cinereus (Palisot de Beauvois 1796). Hoary Bat. Yellow (NS). Uncommon, probably widespread. Migrates. 9 specimen records, 3 sight records (NS MCRD) plus 4 new sight records at Bon Portage Island, Shelburne Co., in 1998-99 (Scott 1999).

?. Eptesicus fuscus (Palisot de Beauvois 1796). Big Brown Bat. Hibernates preferentially in buildings but also in caves and mines. Has been very tentatively identified at Hayes Cave (NS MNH) but not yet confirmed.

ORDER PRIMATES (LEMURS, MONKEYS, APES, HUMANS)

Family Hominidae (Great Apes, Humans)

16. Homo sapiens Linnaeus 1758. Humans, People. Native and invaded/introduced. Common throughout.

\section{ORDER CARNIVORA (CARNIVORES)}

Family Canidae (Wolves, Dogs, Jackals, Foxes)

17. Canis lupus Linnaeus 1758. Grey Wolf (Timber Wolf). ExtiRPated (NS). Not permanently established when Europeans arrived but intermittently present by natural incursion/invasion in the 1780s, c. 1830 and in 1845-47 when last known animal was killed for bounty (Dodds et al. 1969). Recent DNA analysis (Wilson et al. 2000) indicates that eastern Canadian wolves are a separate lineage from the western grey wolves and comprise a distinct species (Canis lycaon) rather than a subspecies of $C$. lupus.

18. Canis latrans Say 1823. Coyote. Green (NS). Prehistorically present in New Brunswick (bones from archaeological site on Passamaquoddy Bay dated c. 2000 ybp; Sanger 1987) and probably in NS. Invaded from New Brunswick in late 1970s; common throughout by mid-1980s (Parker 1995).

19. Alopex lagopus (Linnaeus 1758). Arctic Fox. An extralimital vagrant (1923, 1935), via ice-floes, to Lingan Bay, Cape Breton Island (De Vany 1923).

20. Vulpes vulpes (Linnaeus 1758). Red Fox. GreEN (NS). Common throughout, especially in open habitats.

Family Ursidae (Bears)

21. Ursus americanus Pallas 1780. American Black Bear. NOT AT RISK (COSEWIC 1999); GreEN (NS). Common throughout, most abundant in central and western mainland (NS DNR). 
Family Procyonidae (Raccoons, Lesser Panda)

22. Procyon lotor (Linnaeus 1758). Raccoon. Green (NS). Present when Europeans first arrived but disappeared shortly thereafter; reinvaded via Isthmus of Chignecto in 1860s, at which time aboriginal peoples had no memory of its former presence (Gilpin 1870). Now common on mainland, especially in agricultural and suburban/urban residential areas. History on Cape Breton Island uncertain; Cameron (1958) found no evidence of its presence, but introduced populations may have been temporarily established at times between 1918 and 1954 by escapes/releases from fur farms (Hudgins 1981); recently invaded Cape Breton Island via Canso Strait/Causeway and now occurs as far north as central Victoria Co. (NS DNR).

Family Mustelidae (Weasels, Badgers, Skunks, Otters)

Subfamily Mustelelinae (Weasels, Martens, Ferrets, Polecats)

23. Martes americana (Turton 1806). American Marten. Red (NS). A small relict population exists in Cape Breton Highlands (Scott 2001); extirpated on mainland and successfully reintroduced in Kejimkujik National Park in 1987-1994 from northern New Brunswick stock (Scott 1998b).

24. Martes pennanti (Erxleben 1777). Fisher. YelLow (NS). Extirpated by 1922 (Smith 1940); reintroduced in 1947-48 and 1963-66 (Dodds \& Martell 1971). Widespread and fairly common in mainland, mostly northwest of a line from Yarmouth to the Canso Causeway (NS DNR).

25. Mustela erminea Linnaeus 1758. Ermine (Short-tailed Weasel). Green (NS). Common throughout.

26. Mustela vison Schreber 1777. American Mink. Green (NS). Common throughout, especially near fresh and salt water.

27. Mustela macrodon (Prentiss 1903). Sea Mink. Extinct (COSEWIC 2000). Disappeared around 1894. Reported to have occurred along southwestern NS coast (Anderson 1946).

Subfamily Mephitinae (Skunks)

28. Mephitis mephitis (Schreber 1776). Striped Skunk. GreEN (NS). Historically mainland only, though rare before 1850 (Rand 1933). Abundant on mainland in agricultural areas by 1900; in 1920s began declining drastically from west to east, possibly due to distemper, and was virtually extirpated by 1940s; recolonized the mainland slowly from east to west (Dodds 1969) and now widespread and common. One documented record from southern Cape Breton Island, a roadkilled animal at Glendale, Inverness Co., in 1998 (NS DNR).

Subfamily Lutrinae (Otters)

29. Lontra canadensis (Schreber 1776). River Otter. Green (NS). Common throughout, in fresh and sometimes salt water.

Family Felidae (Cats)

Subfamily Acinonychinae (Cheetah, Cougar)

30. Puma concolor (Linnaeus 1771). Cougar (Puma, Mountain Lion). DATA DEFICIENT (COSEWIC 1998). Red (NS). Some credible sightings/tracks but no photos or specimens. Possibly historically present [in southeast Cape Breton Island] shortly after European arrival (Denys 1672:385-386). Not recorded between then and the late 19th century (Gilpin 1866). Any now in NS would be escaped captive exotic animals, or their descendants (Scott 1998a). 
Subfamily Felinae (Typical cats)

31. Lynx lynx (Linnaeus 1758). Canada Lynx. Not at RISK (COSEWIC 2001); SpeCial CONCERN (NSESA 2001). Throughout the province in 1860s (Gilpin 1866) but extirpated on mainland by 1930 (Rand 1933); now extremely rare in northern mainland as recent vagrants from Cape Breton Island (NS DNR); increasingly rare and restricted to higher elevations on Cape Breton Island, possibly as result of competition with bobcats, which have invaded recently (Parker 2001).

32. Lynx rufus (Schreber 1777). Bobcat (Wildcat). Green (NS). Common on mainland; original status on Cape Breton Island uncertain but not present in 1953 (Cameron 1958); has invaded much of southern Cape Breton Island (NS DNR) since construction of the Canso Causeway.

Family Phocidae (True Seals)

33. Halichoerus grypus (Fabricius 1791). Grey Seal. Not AT RISK (COSEWIC 1999). Locally common on Atlantic, Gulf of St. Lawrence and Bay of Fundy coasts, and on Sable Island where it breeds in large numbers.

34. Phoca vitulina Linnaeus 1758. Harbour Seal. Common in all coastal waters except extreme upper Bay of Fundy, where it is occasional. Breeds on rocky coastal islands, and on Sable Island, where numbers have shown a severe decline recently (Stobo 2002).

35. Phoca groenlandica Erxleben 1777. Harp Seal. Regular and increasingly frequent visitor to Gulf of St. Lawrence and Atlantic coasts, as late winter/early spring juveniles, and occasionally reaching the upper Bay of Fundy (McAlpine \& Walker 1999).

36. Phoca hispida Schreber 1775. Ringed Seal. Extralimital vagrant from arctic and subarctic waters, all juveniles or subadults. First recorded on NS mainland at mouth of the Sackville River, Bedford, in 1993 and 1994; 11 records from Sable Island between 1990 and 1998 (Lucas \& McAlpine 2002).

37. Cystophora cristata (Erxleben 1777). Hooded Seal. NOT AT RISK (COSEWIC 1986). Increasingly frequent visitor to Gulf of St. Lawrence and Atlantic coasts, as late winter/early spring juveniles, and occasionally reaching the upper Bay of Fundy (McAlpine et al. 1999).

Family Odobenidae (Walrus)

38. Odobenus rosmarus (Linnaeus 1758). Atlantic Walrus. ExtiRPATEd (COSEWIC 2000). Formerly bred on Sable Island and the Magdalen Islands; extirpated by late 1600s (Wright 1989). Now a very rare straggler to NS waters from the eastern Arctic, most recently a juvenile photographed at Cape Sable Island in 1976 (NS $\mathrm{MNH}$ ) and an unmistakable juvenile seen on rocks off Pt. Pleasant Park, Halifax, on 6 Feb 2000 (NS MNH).

\section{ORDER CETACEA (WHALES)}

SUBORDER ODONTOCETI (Toothed Whales)

Family Delphinidae (Dolphins)

39. Stenella caeruleoalba (Meyen 1833). Striped Dolphin (Blue Dolphin). NOT AT RISK (COSEWIC 1993). Sable Island (Lucas \& Hooker 2000). Common along Continental Shelf edge in summer (Whitehead 2001).

40. Stenella attenuata (Gray 1846). Pantropical Spotted Dolphin (Slender-beaked Dolphin). One specimen with no locality data but presumably from Nova Scotian waters (NS MNHC, Sergeant et al. 1970). 
41. Stenella frontalis (G. Cuvier 1829). Atlantic Spotted Dolphin (Cuvier's Dolphin). One specimen with no locality data but presumably from Nova Scotian waters (NS MNHC, Sergeant et al. 1970).

42. Delphinus delphis Linnaeus 1758. Common Dolphin (Short-beaked Common Dolphin). NOT AT RISK (COSEWIC 1991). Common offshore.

43. Tursiops truncatus (Montagu 1821). Bottlenose Dolphin. NOT AT RISK (COSEWIC 1993). Bedford Basin 1987 (NS MNHC); West Pennant, Halifax Co. 1993 (MASRD). Occasional offshore in summer (Whitehead 2001).

44. Grampus griseus (G. Cuvier 1812). Risso's Dolphin. NOT AT RISK (COSEWIC 1990). Sable Island 1994 (Lawson and Eddington 1998). Occasional off Continental Shelf edge (Whitehead 2001).

45. Lagenorhynchus albirostris (Gray 1846). White-beaked Dolphin. NOT AT RISK (COSEWIC 1998). Occasional offshore and common inshore, except extreme upper Bay of Fundy, where it is infrequent.

46. Lagenorhynchus acutus (Gray 1828). Atlantic White-sided Dolphin. Not AT RISK (COSEWIC 1998). Common inshore (including occasional pods in Bedford Basin; P. Brodie 2001) and offshore, except extreme upper Bay of Fundy, where it is infrequent.

47. Orcinus orca Linnaeus 1758. Killer Whale (Orca). Data Deficient (COSEWIC 1999). Economy, Colchester Co., 1950 (Sergeant \& Fisher 1957); Sable Island 1972 (Lucas \& Hooker 2000). Uncommon, offshore.

48. Globicephala melas (Traill 1809). Atlantic Long-finned Pilot Whale. NOT AT RISK (COSEWIC 1994). Common inshore and offshore; strands frequently, sometimes in large numbers.

Family Phocoenidae (Porpoises)

49. Phocoena phocoena (Linnaeus 1758). Atlantic Harbour Porpoise (Common Porpoise). Threatened (COSEWIC 1991). Palka (2000) gives total estimates that suggest a summer population of $\sim 24,900$ animals in western NS waters (part of the larger Gulf of Maine-Bay of Fundy population), concentrated within $\sim 70 \mathrm{~km}$ of land from Digby around to eastern Shelburne Co. Uncommon or local inshore around remainder of coasts.

Family Monodontidae (Beluga, Narwhal)

50. Delphinapterus leucas (Pallas 1776). Beluga (White Whale). Endangered (COSEWIC 1997). Fox Point, St. Margaret's Bay, 1965; Bedford Basin 1968 (Sergeant et al. 1970). Extralimital straggler to NS coastal waters from St. Lawrence Estuary or Labrador. Regular if not resident in the Bay of Fundy in the 1740s, in pods of 30-40 animals (Morris 1748); uncommon there in 19th century (Gilpin 1878) and recently (McAlpine 2001). One initially subadult female (known as "Wilma") lived in Guysborough Harbour from 1993 to 1998 (Frohoff et al. 2000); DNA analysis of her skin scrapings revealed a mitochondrial haplotype known only in belugas from the St. Lawrence Estuary (Gladden et al. 1999).

Family Kogiidae (Dwarf and Pygmy Sperm Whales)

51. Kogia breviceps (Blainville 1838). Pygmy Sperm Whale. Not AT RISK (COSEWIC 1994). Halifax Harbour 1920 (Piers 1923), Sable Island 1969 (Sergeant et al. 1970). Very rare.

52. Kogia simus (Owen 1866). Dwarf Sperm Whale. Sable Island, 1971 and 1996 (Lucas \& Hooker 2000). Very rare. 
Family Physeteridae (Sperm Whale)

53. Physeter macrocephalus (Linnaeus 1758). Sperm Whale. NOT AT RISK (COSEWIC 1996). Sable Island 1964 (Sergeant et al. 1970), 1990 (Lucas \& Hooker 2000); Petit-de-Grat, Cape Breton Co. 1991; Cherry Hill, Lunenburg Co. 1994; River John, Cumberland Co. 1994 (Reeves \& Whitehead 1997); Point Aconi, Cape Breton Co. 1998 (MASRD). One live sighting 20 km NW of Brier Island, 1981 (McAlpine 1985); common offshore in deeper water (Whitehead 2001).

Family Ziphiidae (Beaked Whales)

54. Hyperoodon ampullatus (Forster 1770). Northern Bottlenose Whale. SPECIAL CONCERN (Gully population; COSEWIC 1996). Sable Island 1968 (Sergeant et al. 1970); Noel Head, Hants Co., 1969 (Mitchell \& Kozicki 1975); Sydney River 1992 (MASRD). Continental shelf/slope waters (Sutcliffe \& Brodie 1977). A significant concentration of about 200 animals lives nearly year-round over the Gully, a submarine canyon $\sim 50 \mathrm{~km}$ east of Sable Island (Whitehead et al. 1997).

55. Mesoplodon mirus True 1913. True's Beaked Whale. Not AT RISK (COSEWIC 1989). St. Anns Bay, Victoria Co., 1938 (Allen 1939). In deeper water, rare (Whitehead 2001).

56. Mesoplodon densirostris (Blainville 1817). Blaineville's BeakedWhale. Not AT RISK (COSEWIC 1989). Peggys Cove 1940 (Raven 1942); Fourchu Bay 1968 (Sergeant et al. 1970). In deeper water, rare (Whitehead 2001).

57. Mesoplodon bidens (Sowerby 1804). Sowerby's Beaked Whale. SPECIAL CONCERN (COSEWIC 1989). Sable Island, 1997 (Lucas \& Hooker 2000). In deeper water (Hooker \& Baird 1999).

\section{SUBORDER MYSTICETI (BALEEN WHALES)}

Family Eschrichtidae (Grey Whale)

58. Eschrichtius robustus (Lilleborg 1861). Atlantic Grey Whale. ExtiRPATEd (COSEWIC 2000). Continental shelf waters, summering from Cape Cod to Labrador; extirpated by end of 18th century (Reeves \& Mitchell 1987).

Family Balaenopteridae (Rorquals)

Most species listed are migratory, and the numbers passing our coasts on northward/ southward migration may be much higher than the numbers actually summering in our waters (Brodie 2001).

59. Balaenoptera acutorostrata Lacépède 1804. Minke Whale. Common inshore and offshore. Apparently not migratory (Whitehead 2001).

60. Balaenoptera borealis Lesson 1828. Sei Whale. Shubenacadie, Hants Co., 1997 (MASRD). Moderately common offshore, very occasional inshore. Possibly not migratory (Whitehead 2001).

61. Balaenoptera physalus (Linnaeus 1758). Fin Whale (Finback Whale). SPECIAL CONCERN (COSEWIC 1987). Occasional inshore, especially at mouth of Bay of Fundy and off Halifax; moderately common offshore.

62. Balaenoptera musculus (Linnaeus 1758). Blue Whale. SpeCial Concern (COSEWIC 1983). Sable Island 1958 (Sergeant et al. 1970), and 1974 (Lucas \& Hooker 2000). Uncommon, offshore only.

63. Megaptera novaeangliae (Borowski 1781). Humpback Whale. SPECIAL CONCERN (COSEWIC 1985). Point Michaud, Richmond Co., 2001 (MASRD) Locally common inshore and offshore in summer, especially around southwestern NS. 
Family Balaenidae (Right and Bowhead Whales)

64. Eubalaena glacialis (Müller 1776). Northern Right Whale. Endangered (COSEWIC 1990). Pugwash, Cumberland Co. 1954 (Sergeant et al. 1970); Long Island, 1995 (NS MNHC); a whale floating dead in shipping lanes $22 \mathrm{~km}$ north of Long Island in 1998 was towed ashore there and necropsied (Knowlton \& Kraus 2001). An increasing number summers in and near mouth of the Bay of Fundy at the same time as the former large summer concentration on Browns Bank (Winn et al. 1986) has declined; virtually none have been seen there since 1997 (Tobin 2001). Two were seen off Chebucto Head, Halifax Co., in Feb 1987, and one was observed by people on a yacht in Bedford Basin in June 1991 (Brodie 2001). Recent DNA analysis (Rosenbaum et al. 2000) indicates that the North Atlantic and North Pacific populations, formerly considered subspecies, are specifically distinct.

ORDER PERISSODACTYLA (ODD-TOED UNGULATES)

Family Equidae (Horses, Asses, Zebras)

65. Equus caballus Linnaeus 1758. Horse (Domestic Horse). A feral population has been established on Sable Island since 1738 (Christie 1980).

\section{ORDER ARTIODACTYLA (EVEN-TOED UNGULATES)}

Family Suidae (Pigs)

66. Sus scrofa Linnaeus 1758. European Wild Hog (European Wild Boar). Feral on Roberts Island, a fenced private hunting preserve in Yarmouth Co. (NS DNR).

Family Cervidae (Deer, Moose)

67. Rangifer tarandus (Linnaeus 1758). Woodland Caribou. ExtiRPated (NS). The last one was shot on the Cape Breton Highlands in 1921; there have been two failed reintroduction attempts, in the Liscomb Game Sanctuary in 1939 and the eastern Cape Breton Highlands in the late 1960s (Benson \& Dodds 1977).

68. Odocoileus virginianus (Zimmerman 1780). White-tailed Deer. Green (NS). Present 1000 ybp; absent when Europeans first arrived; reinvaded/reintroduced 1894-1910 (Benson \& Dodds 1977). Now common throughout.

69. Alces alces (Linnaeus 1758). Moose (American Moose). Red (NS). Extirpated on Cape Breton Island in 1924 and reintroduced from Alberta in 1947-48; now common there. Uncommon to rare on mainland, and declining in some areas, especially in the southwest (Pulsifer \& Nette 1995; NS DNR).

\section{ORDER RODENTIA (RODENTS)}

Family Sciuridae (Squirrels, Marmots)

70. Tamias striatus (Linnaeus 1758). Eastern Chipmunk. GreEN (NS). Common throughout in drier forest, forest-edge and shrub habitats, especially rocky ones (NS MCRD).

71. Marmota monax (Linnaeus 1758). Woodchuck (Groundhog). Green (NS). Hibernates. Common in grassy habitats on mainland, including highway verges in forested regions (NS MCRD). Not yet reported from Cape Breton Island (NS DNR), probably because it is not active in winter and thus cannot use the ice route across the strait.

72. Sciurus carolinensis Gmelin 1788. Grey Squirrel. One black specimen reported from Cumberland Co. (Gilpin 1870); repeatedly introduced in the 20th century, once in the Tobeatic Game Sanctuary (Banfield 1974) and often in towns (e.g., Wolfville, Kentville, Halifax, Amherst), but never established (NS MNH). 
73. Tamiasciurus hudsonicus (Erxleben 1777). American Red Squirrel. GreEN (NS). Common throughout in mixed and coniferous forest and forest-edge habitats of all ages; numbers fluctuate irregularly (NS MCRD). A pair was released on Seal Island in the early 1970s (McLaren 2001) and a population is still present.

74. Glaucomys volans (Linnaeus 1758). Southern Flying Squirrel. VuLNERABLE (COSEWIC 1988). Yellow (NS). Disjunct. First discovered in Kejimkujik NP in 1971 (Wood \& Tessier 1974 - their cited 1962 [not 1967] Acadia University specimen from Pebbleoggitch Lake, catalog no. Ma 541, is actually a small G. sabrinus); the upper Gaspereau Valley, Kings Co. in 1984 (Elderkin 1987); Kentville Ravine, Kings Co., in 1998 (NS DNR). Current research by an Acadia graduate student has added 2 new sites within the park, 5 others immediately to the east and southeast outside the park, and documented outlying populations at Bear River and Middleton, Annapolis Co., Falmouth, Hants Co., Cookville, Lunenburg Co. and Ponhook Lake, Queens Co. (Lavers 2001).

75. Glaucomys sabrinus (Shaw 1801). Northern Flying Squirrel. Green (NS). Common throughout in forest habitats with tree cavities; regularly occupies bird nestboxes in suburban areas adjoining forests (NS MCRD). Often completely syntopic with G. volans where the latter occurs (Lavers 2001)

Family Castoridae (Beavers)

76. Castor canadensis Kuhl 1820. American Beaver. Green (NS). Nearly extirpated by trapping about 1840 but began to recover in southwestern NS by the late 1930s (Smith 1940). Now common throughout in suitable wetlands.

Family Muridae (Typical Voles, Rats, Mice)

Subfamily Arvicolinae (Voles, Lemmings)

77. Clethrionomys gapperi (Vigors 1830). Red-backed Vole (Gapper's Red-backed Vole, Southern Red-backed Vole). GreEN (NS). By far the most abundant forest rodent; throughout in all forest, forest-edge and tall shrub habitats (NS MCRD). Populations around Barrington Passage, Shelburne Co., are unique in having a high incidence (14 - 50\%) of melanistic animals, usually completely black (NS MCRD).

78. Synaptomys cooperi Baird 1858. Southern Bog Lemming. GreEN (NS). Rarely found in bogs in NS; generally rare and very local in forest habitats, especially rocky ones, except on periphery of Cape Breton Highlands where it is fairly common on forested talus slopes (NS MCRD).

79. Ondatra zibethicus (Linnaeus 1766). Muskrat. Green (NS). Common throughout in wetlands (NS MCRD). Introduced to Seal Island in the early 1990s and now well established (McLaren 2001).

80. Microtus pennsylvanicus (Ord 1815). Meadow Vole ("meadow mouse", "field mouse"). Green (NS). Common throughout in grass, forb and low shrub habitats, including many inshore islands (NS MCRD). Populations can show extreme fluctuations regionally or locally. The unique population on Bon Portage Island has a high incidence $(>50 \%)$ of animals with occipital markings ranging from a few white hairs to a 1-cm white blaze (Bondrup-Nielsen 2001), and occasional almost complete leucism (Parsons \& Bondrup-Nielsen 1995).

81. Microtus chrotorrhinus (Miller 1894). Rock Vole (Yellow-nosed Vole). Green (NS). Disjunct. Discovered in 1974 (Roscoe \& Majka 1976). Locally common on forested talus on periphery of Cape Breton Highlands (NS MCRD). 
Subfamily Murinae (Old World Rats and Mice)

82. Rattus rattus Linnaeus 1758. Black Rat (Roof Rat). GreEN (NS). Introduced in many ports and established in some, but did not persist after 1860s. In January 1995 a small breeding population was discovered at Pier 21 in Halifax, the first known occurrence since 1861 (NS MNHC). The rats apparently came from Cuba and were still present and breeding in early 1996, despite control efforts; none have been taken since October 1999 (NS MNH).

83. Rattus norvegicus (Berkenhout 1769). Brown Rat (Norway Rat). Green (NS). Introduced. Common in urban and some rural and agricultural areas. Established on Seal Island from a World War II shipwreck (Erskine 1955).

84. Mus domesticus Rutty 1772. House Mouse. Green (NS). Introduced. Common in urban and some rural and agricultural areas.

Subfamily Sigmodontinae (New World Rats and Mice)

85. Peromyscus maniculatus (Wagner 1845). Deer Mouse. Green (NS). Throughout in forest, forest-edge and tall shrub habitats; tends to be uncommon and local in western mainland where $P$. leucopus also occurs, and absent in coastal strip from Halifax to Digby (NS MCRD). A morphologically and behaviourally distinct population occurs on Isle Haute in the upper Bay of Fundy (Pulsifer 1984).

86. Peromyscus leucopus (Rafinesque 1818), subspecies caudatus Smith 1939. White-footed Mouse. Green (NS). Disjunct. Common in forest, forest-edge and tall shrub habitats from Hants and western Halifax Counties westward, very local in central and eastern NS (Pomquet, Pictou Co. and lower St Mary's River valley, Guysborough Co.); absent from northwest mainland and Cape Breton Island (NS MCRD).

Family Dipodidae (Jerboas, Jumping Mice)

Subfamily Zapodinae (Jumping Mice)

87. Napaeozapus insignis (Miller 1891). Woodland Jumping Mouse. GreEN (NS). Hibernates. Common in moist deciduous and mixed forests and tall shrub habitats throughout, especially along streams.

88. Zapus hudsonius (Zimmerman 1780). Meadow Jumping Mouse. GreEN (NS). Hibernates. Locally common throughout in poorly-drained oldfield, meadow and low shrub habitats.

Family Erethizontidae (New World Porcupines)

89. Erethizon dorsatum (Linnaeus 1758). American Porcupine. Green (NS). Common throughout mainland in mixed and coniferous forests; established in eastern Cape Breton Island, probably as a result of human transport (NS DNR).

ORDER LAGOMORPHA (PIKAS, HARES, RABBITS)

Family Leporidae (Hares, Rabbits)

90. Lepus americanus Erxleben 1777. Snowshoe Hare (Varying Hare, "rabbit"). GreEN (NS). Common throughout, with more extreme cyclic fluctuations in Cape Breton Island (Dodds 2001). Introduced to Seal Island in the early 1970 s and now common (McLaren 2001).

91. Lepus timidus Linnaeus 1758. Arctic Hare. Eight females and four males introduced from Brunette I., Newfoundland, to Scatarie Island, off eastern tip of Cape Breton Island, in 1975; last confirmed present in 1981; none detected in 1987 and 1989 surveys (NS DNR). 


\section{Discussion}

Nova Scotia's location at mid-latitudes $\left(43^{\circ} 23^{\prime} \mathrm{N}\right.$ to $\left.47^{\circ} 02^{\prime} \mathrm{N}\right)$ on the east coast of North America has given it elements of both cold temperate and warm temperate mammal communities. Its northeast-to-southwest alignment and narrow connection to the mainland at the midpoint of its length (Fig. 1) have resulted in an unusually high percentage of disjunct species, as past climate zones have shifted north or south, isolating populations at either end of the province. Only three species of mammal (Table 1) have established themselves by invasion through the isthmus in historic times.

This disjunction process has not been limited to mammals. Large numbers of disjuncts also occur in the vascular plants, including 56 Arctic-Alpine (northern) and 21 Coastal Plain (southern) species (Roland 1998). There are many disjunct invertebrates including 10 unionid clams (all NS species also occur in New Brunswick but far from contiguously, and the disjunctions range from only a few watersheds to nearly $700 \mathrm{~km}$ (Davis 2002)), 13 butterflies (Layberry et al. 1998) and 13 Odonata (Brunelle 1998). Among the lower vertebrates, $15.6 \%$ of amphibians, $33 \%$ of reptiles (Gilhen 1984) and $25 \%$ of our non-diadromous freshwater fishes (Gilhen 2001) are disjunct.

Nova Scotia has six disjunct species of terrestrial mammals (Table 1.), all small insectivores and rodents and all relatively slow dispersers. These comprise $14.3 \%$ of native non-flying terrestrial mammals, $33 \%$ of the insectivores and $18.8 \%$ of native rodents. They represent both northern (Arctic Shrew, Gaspé Shrew, Rock Vole) and southern (Long-tailed Shrew, Southern Flying Squirrel, White-footed Mouse) distributions. These disjunctions are also fairly old (probably several thousands of years, on average) and the isolated populations may harbour significant variants of the species' respective genomes. No other similar-sized area in the United States or Canada has such high proportions of disjunct mammals.

Table I Summary of land-breeding species.

\begin{tabular}{|c|c|c|}
\hline Category & No. & Species \\
\hline Native species & 48 & \\
\hline non-marine & 46 & \\
\hline marine (seals) & 2 & Grey Seal, Harbour Seal \\
\hline Disjunct species: & 6 & $\begin{array}{l}\text { Arctic Shrew, Gaspé Shrew, Long-tailed } \\
\text { Shrew, Southern Flying Squirrel, Rock Vole, } \\
\text { White-footed Mouse }\end{array}$ \\
\hline Established in wild by invasion: & 3 & Coyote, Raccoon, White-tailed Deer \\
\hline Established in wild by introduction: & 6 & $\begin{array}{l}\text { White-tailed Deer, European Wild Hog, Horse, } \\
\text { Brown Rat, Black Rat, House Mouse }\end{array}$ \\
\hline Introduced but not established: & 2 & Grey Squirrel, Arctic Hare \\
\hline Extirpated: & 4 & $\begin{array}{l}\text { Grey Wolf, Atlantic Walrus, Atlantic Grey Whale, } \\
\text { Woodland Caribou }\end{array}$ \\
\hline Extinct: & 1 & Sea Mink \\
\hline
\end{tabular}

Given Nova Scotia's small area and long history of European settlement, its mammal fauna turned out to be very poorly known. The recent completely unexpected discovery of four small mammal species (Gaspé Shrew, Southern Flying Squirrel in 1971, Rock Vole in 1974, Long-tailed Shrew in 1984) was the direct result of systematic and intensive trapping surveys (500 to >1500 trap-nights per site), which had never previously been done in the province. Prior to that, collecting had been carried out by 


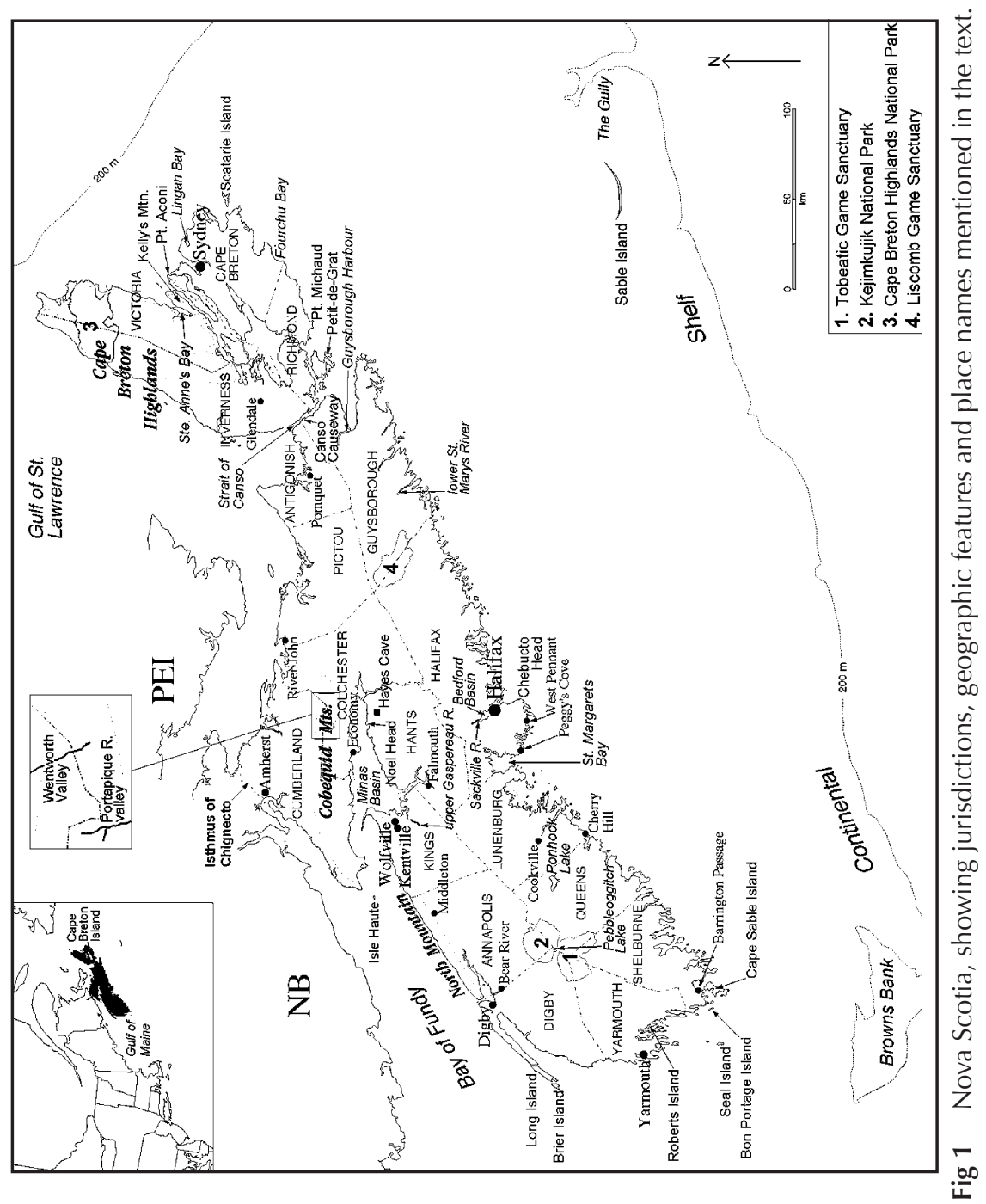


mammalogists working for museums, with the primary goal of producing quality museum specimens, and they had limited their trapping effort to no more than would produce a full day's work of study-skin preparation, or 10 to 12 animals per person. This usually meant in the vicinity of 100-150 traps set per night, which is simply not enough effort to reliably catch the rarest species. In addition, early collectors apparently never trapped the extensive forested talus in the Cobequid Mountains or Cape Breton Highlands (where three of the four new species were found), presumably because it is steep and sometimes dangerous and they had no reason to believe there was anything up there that they could not also find where the going was easier and safer.

Cape Breton Island has historically had a depauperate mammal fauna (Cameron 1958), lacking 8 species that were present on the adjacent mainland (Arctic Shrew, Smoky Shrew, Bobcat, Striped Skunk, Raccoon, White-footed Mouse, Woodchuck, Porcupine). The building of the Canso Causeway across the Strait of Canso in 1953-55 had a major zoogeographic impact, as it caused the western third of the strait to freeze over in winter and allowed the invasion and establishment on Cape Breton Island of four large mammal species (Coyote, Raccoon, Striped Skunk and Bobcat) and the perhaps temporary reoccupation of the mainland by one (Canada Lynx). Woodchucks, being hibernators, have not been able to use the frozen strait as an invasion route; if they are to colonize Cape Breton Island on their own it will have to be via the causeway itself, which is not likely to happen since the $1.2-\mathrm{km}$ paved roadway is bordered only by virtually unvegetated loose boulders.

The mammal list is not necessarily complete. There is a slight possibility that another species, the Northern Bog Lemming (Synaptomys borealis), occurs at higher elevations in the Cape Breton Highlands. Its distribution is very similar to that of the Rock Vole (Microtus chrotorrhinus), with populations on the north shore of the Gulf of St. Lawrence, and in the Gaspé Peninsula and northern New Brunswick (Banfield 1974). It prefers Black Spruce bogs, which occur extensively on the highlands (Davis \& Browne 1996).

There are still major gaps in our knowledge of some mammal distributions as well. For example, there are very extensive forested talus slopes on the eastern end of North Mountain which are suitable habitat for the Long-tailed Shrew (Woolaver et al. 1998) but we do not yet know if it occurs there. There also may be additional fragmented populations of White-footed Mouse on the eastern mainland.

\section{Acknowledgements}

We are particularly grateful to four people who not only critically reviewed the manuscript but made many useful suggestions and supplied important supplementary information in their areas of expertise as well as some references we had missed: Don McAlpine, Curator of Zoology at the New Brunswick Museum, Saint John (whales, seals), Hal Whitehead, Department of Biology, Dalhousie University, Halifax (whales); Paul Brodie (whales), and Don Dodds (carnivores, artiodactyls). We also thank the staff of the Nova Scotia Department of Natural Resources in Kentville (Barry Sabean, Director of Wildlife), Baddeck (Don Anderson) and Sydney (Terry Power and Dave Harris, respectively the incoming and retiring regional biologists) for responding to specific requests for information, notably the details of the Arctic Hare introduction tracked down and supplied by Barry, Terry and Dave, and the Cape Breton Island roadkilled skunk record provided by Don. Amanda Lavers, a graduate student at Acadia University Biology Department, kindly provided details of newly discovered southern flying squirrel populations; she also forwarded to us the Yarmouth red bat 
photos and information. Michael Deal of Memorial University of Newfoundland, St. Johns, confirmed that some alleged precontact archaeological records of Arctic Fox and Arctic Hare in Nova Scotia did not in fact exist. Cathy Kinsman of the Whale Stewardship Program, Dartmouth NS, provided us with relevant literature on Wilma, the beluga that lived in Guysborough Harbour. Ron Arsenault of Moncton NB was helpful in resolving the history of raccoons on Cape Breton Island. Ed Trippel, Dept. of Fisheries and Oceans, Saint Andrews Biological Station, NB, and Andrew Read of Duke University Marine Laboratory, Beaufort NC, helped us pick out the essentials from the voluminous recent literature on Harbour Porpoises. Amy Knowlton of the New England Aquarium provided the reference for the right whale necropsied on Long Island. Deborah Tobin of East Coast Ecosystems, Freeport NS, commented on our treatment of cetacean records and provided an update on the former Browns Bank concentration of northern right whales. Don Stewart, Acadia University Biology Department, gave us a copy of his submitted paper on the newly recognized Sorex maritimensis, and Zoe Lucas and Don McAlpine also provided a copy of their submitted paper on Sable Island ringed seal records. Ian McLaren supplied the latest information on the Seal Island mammal introductions. Wayne Stobo clarified the status of the harbour seals breeding on Sable Island. David Christianson of the Nova Scotia Museum supplied the 1748 account by C. Morris of belugas in the Bay of Fundy. Shannon Gowans and Jerry Conway helped us obtain some needed whale references. Brian Beck, Calum Ewing, Alex Wilson, Mark Elderkin and Sherman Boates also read and commented on the manuscript.

\section{References}

Allen GM (1939) True's beaked whale in Nova Scotia. J Mamm 20:259-260

Anderson RM (1946) Catalogue of Canadian recent mammals. Nat Mus Can Bull 102

Banfield AW (1974) The mammals of Canada. University of Toronto Press, Toronto

Benson DW, Dodds DG (1977) The deer of Nova Scotia. Nova Scotia Department of Lands and Forests, Halifax

Bondrup-Nielsen S (2001) (Department of Biology, Acadia University, Wolfville NS) Personal communication

Brodie PF (2001) (Marine Mammals Div, DFO, Bedford Inst Oceanography, Dartmouth NS [retired]) Personal communication

Brunelle P-M (1998) The status of Somatochlora brevicincta Robert 1954 (Odonata, Anisoptera, Corduliidae) in Nova Scotia. Nova Scotia Museum, Halifax

Cameron AW (1958) Mammals of the islands in the Gulf of St. Lawrence. Nat Mus Can Bull 154

Christie BJ (1980) The horses of Sable Island. Petheric Press, Halifax

Davis DS (2002) (Nova Scotia Museum, Halifax [retired]) Personal communication

Davis DS, Browne S (1996) The natural history of Nova Scotia, Vol 2. Theme regions. Nimbus Publishing and Nova Scotia Museum, Halifax

Denys N (1672) Description geographical and historical of the coasts of North America, with the natural history of the country, Vol 2. Natural history of the people, of the animals, of the trees and plants of North America, and of its diverse climates. Translated and edited by WF Ganong, 1908. Champlain Society, Toronto

De Vany JL (1923) Arctic Fox shot in Cape Breton. Can Field-Nat 37:118

Dodds DG (1969) The striped skunk, Mephitis mephitis (Schreber) in Nova Scotia. Can Field-Nat 83:229-233 
Dodds DG (2001) (Department of Biology, Acadia University, Wolfville NS [retired]) Personal communication

Dodds DG, Martell A (1971) The recent status of the fisher, Martes pennanti pennanti (Erxleben), in Nova Scotia. Can Field-Nat 85:62-65

Dodds DG, Mullen E, Martell A (1969) Notes on the rare and extinct Carnivora of Nova Scotia. Wildlife Museum, Acadia University, Wolfville, NS. Unpublished data

Elderkin MF (1987) The breeding and feeding ecology of a Barred Owl, Strix varia Barton, population in Kings County, Nova Scotia. MSc thesis, Acadia University, Wolfville, NS

Erskine JS (1955) Seal Island. J Educ Halifax $5^{\text {th }}$ series 5:26-36

Frohoff TG, Kinsman C, Rose NA, Sheppard K (2000) Three occurrences of solitary, sociable Beluga Whales (Delphinapterus leucas) in eastern Canada. Proceedings of the 2000 American Cetacean Society Conference, Monterey Bay, CA

Fumagalli L, Taberlet P, Stewart DT, Gielly L, Hausser J, Vogel P (1999) Molecular phylogeny and evolution of Sorex shrews inferred from mitochondrial DNA sequence data. Mol Phylogen Evol 11:222-235

Gilhen JA (1984) Amphibians and reptiles of Nova Scotia. Nova Scotia Museum, Halifax

Gilhen JA (2001) (Nova Scotia Museum, Halifax [retired]) Personal communication

Gilpin JB (1866) On the Mammalia of Nova Scotia, No II. Proc Trans NS Inst Nat Sci 1:8-15

Gilpin JB (1870) On the Mammalia of Nova Scotia, No IV. Proc Trans NS Inst Nat Sci 2:58-69

Gilpin JB (1878) On the smaller cetaceans inhabiting the Bay of Fundy and shores of Nova Scotia. Proc Trans NS Inst Nat Sci 4:21-34

Gladden JGB, Brodie PF, Clayton JW (1999) Mitochondrial DNA used to identify an extralimital beluga whale (Delphinapterus leucas) from Nova Scotia as originating from the St. Lawrence population. Mar Mamm Sci 15:556-558

Hudgins EJ (1981) The productivity of the raccoon Procyon lotor L in Nova Scotia. MSc thesis, Acadia University, Wolfville, NS

HermanTB, Scott FW (1992) Global change at the local level: assessing the vulnerability of vertebrate species to climatic warming. In: Willison JHM, Bondrup-Nielsen S, Drysdale C, Herman TB, Munro NWP, PollockTL (eds) Science and the management of protected areas: developments in landscape management and urban planning, 7. Elsevier, Amsterdam, p 353-367

Janczewski DN, Modi WS, Stephens JC, O'Brien SJ (1995) Molecular evolution of mitochondrial 12S RNA and cytochrome b sequences in the pantherine lineage of Felidae. Mol Biol Evol 12:690-707

Knowlton AR, Kraus SD (2001) Mortality and serious injury of northern right whales (Eubalaena glacialis) in the western North Atlantic Ocean. J Cetacean Res Manag (special issue) 2:193-208.

Laberry RA, Hall PW, Lafontaine DJ (1998) The butterflies of Canada. University of Toronto Press, Toronto

Lavers A (2001, 2002) (Department of Biology, Acadia University, Wolfville NS) Personal communication

Lawson JW, Eddington JD (1998) A first eastern Canadian stranding record for Risso's dolphin, Grampus griseus. Northeastern Nat 5:215-218

Lucas ZN, Hooker SK (2000) Cetacean strandings on Sable Island, Nova Scotia, 19701998. Can Field-Nat 114:45-61

Lucas ZN, McAlpine DF (2002) Extralimital occurrences of Ringed Seals, Phoca hispida, on Sable Island, Nova Scotia. Can Field-Nat 116:607-610 
McAlpine DF (1985) First records of the sperm whale (Physeter catodon) from New Brunswick and the Bay of Fundy. Nat Can (Que) 112:433-434

McAlpine DF (2001) (New Brunswick Museum, Saint John NB) Personal communication McAlpine DF, Stevick PT, Murison LD, Turnbull SD (1999) Extralimital records of Hooded Seals (Cystophora cristata) from the Bay of Fundy and northern Gulf of Maine. Northeast Nat 6:225-230

McAlpine DF, Walker RJ (1999) Additional extralimital records of the Harp Seal, Phoca groenlandica, from the Bay of Fundy, New Brunswick. Can Field-Nat 113: 290-292

McLaren IA (2001) (Department of Biology, Dalhousie University, Halifax) Personal communication

Mitchell E, Kozicki VM (1975) Autumn stranding of a Northern Bottlenose Whale (Hyperoodon ampullatus) in the Bay of Fundy, Nova Scotia. J Fish Res Bd Can 32:1019-1040

Morris C (1748) A brief survey of Nova Scotia with an account of the several attempts of the French this war to recover it out of the hands of the English. NAC, MG18, F10, National Archives of Canada, Ottawa.

Palka D (2000) Abundance of the Gulf of Maine/Bay of Fundy harbor porpoise based on shipboard and aerial surveys during 1999. Northeast Fisheries Science Center Reference Document 00-07, Woods Hole, MA

Parker G (1995) Eastern Coyote: the story of its success. Nimbus Publishing, Halifax

Parker G (2001) Status report on the Canada Lynx in Nova Scotia. Nova Scotia Department of Natural Resources, Kentville, NS

Parsons GJ, Bondrup-Nielsen S (1995) Partial albinism in an island population of meadow voles, Microtus pennsy/vanicus, from Nova Scotia. Can Field-Nat 109:263-264

Peterson RL (1966) The mammals of eastern Canada. Oxford University Press, Toronto

Piers H (1923) Accidental occurrence of the pygmy sperm whale on the coast of Nova Scotia. Proc Trans NS Inst Sci 15:95-114

Pulsifer MD (1981) Comparative morphology and demography of Peromyscus maniculatus Wagner from Isle Haute and mainland Nova Scotia. BSc thesis, Acadia University, Wolfville, NS

Pulsifer MD, Nette TL (1995) History, status and present distribution of moose in Nova Scotia. N Am Moose Conf Workshop 31:209-219

Rand AL (1933) Notes on the mammals of the interior of western Nova Scotia. Can Field-Nat 47:41-50

Raven HC (1942) On the structure of Mesoplodon densirostris, a rare beaked whale. Bull Am Mus Nat Hist 80:23-50

Reeves RR, Mitchell E (1987) Status report on the Gray Whale Eschrichtius robustus in Canada. Committee on the Status of Endangered Wildlife in Canada (COSEWIC), Canadian Wildlife Service, Environment Canada, Ottawa

Reeves RR, Whitehead H (1997) Status of the Sperm Whale, Physeter macrocephalus, in Canada. Can Field-Nat 111:293-307

Roland AE (1998) Roland's Flora of Nova Scotia. Nimbus Publishing and Nova Scotia Museum, Halifax

Roscoe B, Majka C (1976) First records for the rock vole (Microtus chrotorrhinus) and the Gaspé shrew (Sorex gaspensis) from Nova Scotia and second record of the Thompson's pygmy shrew (Microsorex thompsoni) from Cape Breton Island. Can Field-Nat 90:497-498

Rosenbaum HC, Brownell RL Jr, Brown MW, Schaeff C and 16 others (2000) Worldwide genetic differentiation of Eubalaena: questioning the number of right whale species. Mol Ecol 9:1793-1802 
Sanger D (1987) The Carson site and the late Ceramic Period in Passamaquoddy Bay, New Brunswick. Archaeological Survey of Canada Paper No 135, National Museums of Canada, Ottawa

Scott FW (1995, 1999) (Wildlife Museum, Biology Dept., Acadia University) Unpublished data

Scott FW (1985) Hibernating bats. In: Morris L (ed) The Hayes Cave site, South Maitland, Nova Scotia. Nova Scotia Museum Curat Report 50:116-121

Scott FW (1987) First record of the Long-tailed Shrew, Sorex dispar, for Nova Scotia. Can Field-Nat 101:404-407

Scott FW (1988) Sorex gaspensis Anthony \& Goodwin 1924, Gaspé Shrew. Committee on the Status of Endangered Wildlife in Canada (COSEWIC), Canadian Wildlife Service, Environment Canada, Ottawa

Scott FW (1998a) Recent history of American Marten (Martes americana) in Nova Scotia. Wildlife Division, Nova Scotia Department of Natural Resources, Kentville, NS

Scott FW (1998b) Update COSEWIC status report on Cougar (Puma concolor couguar) [eastern population]. Committee on the Status of Endangered Wildlife in Canada (COSEWIC), Canadian Wildlife Service, Environment Canada, Ottawa

Scott FW (2001) Status of the American Marten, Martes americana, on Cape Breton Island, Nova Scotia. Wildlife Division, Nova Scotia Department of Natural Resources, Kentville, NS

Scott FW, van Zyll de Jong CG (1989) New Nova Scotia records of the Long-tailed Shrew, Sorex dispar, with comments on the taxonomic status of Sorex dispar and Sorex gaspensis. Nat Can (Que) 116:145-154

Sergeant DF, Fisher HD (1957) The smaller Cetacea of eastern Canadian waters. J Fish Res Bd Can 14:83-115

Sergeant DE, Mansfield AW, Beck B (1970) Inshore records of Cetacea for Eastern Canada, 1949-68. J Fish Res Bd Can 27:1903-1915

Smith RW (1940) The land mammals of Nova Scotia. Am Midl Nat 24:213-241

Stewart DT, Baker AJ (1992) Genetic differentiation and biogeography of the masked shrew in Atlantic Canada. Can J Zool 70:106-114

Stewart DT, Perry N, Fumagalli L (2002) The maritime shrew, Sorex maritimensis (Insectivora: Soricidae), a newly recognized Canadian endemic. Can J Zool 80:94-99

Stobo W (2002) (Marine Fish Div, DFO, Bedford Instit Oceanography, Dartmouth NS) Personal communication

Sutcliffe WH, Brodie PF (1977) Whale distributions in Nova Scotia waters. Can Fish Mar Serv Tech Rep 722

Taylor J (1997) The development of a conservation strategy for the hibernating bats of Nova Scotia. BSc thesis, Dalhousie University, Halifax

Tobin D (2001) (East Coast Ecosystems, Freeport NS) Personal communication

van Zyll de Jong CG (1983) Handbook of Canadian mammals, Vol 1. Marsupials and insectivores. National Museums of Canada, Ottawa

van Zyll de Jong CG (1985) Handbook of Canadian Mammals, Vol 2. Bats. National Museums of Canada, Ottawa

Volobouev VT, van Zyll de Jong CG (1988) The karyotype of Sorex arcticus maritimensis (Insectivora, Soricidae) and its systematic implications. Can J Zool 66:1968-1972

Whitehead H (2001) (Department of Biology, Dalhousie University, Halifax) Personal communication 
Whitehead H, Faucher A, Gowans S, McCarrey S (1997) Status of the Northern Bottlenose Whale, Hyperoodon ampullatus, in the Gully, Nova Scotia. Can FieldNat 111:287-292

Wilson DE, Reeder DM (eds) (1993) Mammal species of the world: a taxonomic and geographic reference, 2nd edn. Smithsonian Institution Press, Washington, DC

Wilson PJ, Grewal S, Lawford ID, Heal JNM and 11 others (2000) DNA profiles of the eastern Canadian wolf and the red wolf provide evidence for a common evolutionary history independent of the gray wolf. Can J Zool 78:2156-2166

Winn HE, Price CA, Sorensen PW (1986) The distributional biology of the right whale (Eubalaena glacialis) in the western North Atlantic. In: Brownell RL Jr, Best PB, Prescott JH (eds) Right whales: past and present status. Proceedings of a Workshop on the Status of Right Whales. Reports of the International Whaling Commission, Special Issue 10, Cambridge, UK, p 129-138

Wood T, Tessier G (1974) First records of the eastern flying squirrel, Glaucomys volans, for Nova Scotia. Can Field-Nat 88:83-84

Woolaver LG, Elderkin MF, Scott FW (1998) Sorex dispar in Nova Scotia. Northeastern Nat 5:323-330

Wright B (1989) The fauna of Sable Island. Nova Scotia Museum Curat Report 68. 